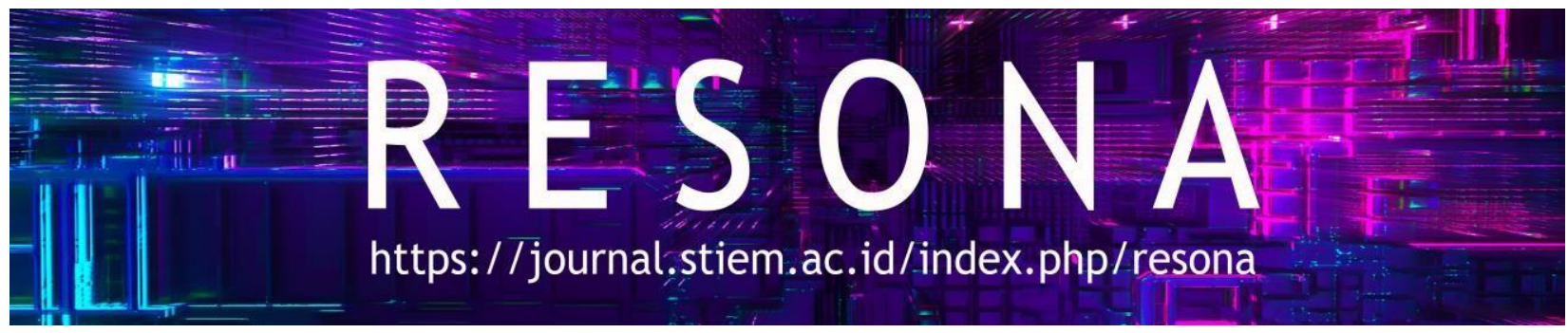

\title{
Pengabdian Kefarmasian “Ayo Buang Sampah Obat" di Kelurahan Latuppa Kecamatan Mungkajang Kota Palopo Provinsi Sulawesi Selatan
}

\author{
Ervianingsih ${ }^{1}$, Hurria ${ }^{2}$, Chitra Astari ${ }^{3}$, Izal Zahran ${ }^{4}$, Murni Mursyid ${ }^{5}$, Al Syahril Samsi ${ }^{6}$ \\ 1,2,3,4,5,6 Universitas Muhammadiyah Palopo
}

\begin{tabular}{l} 
INFO NASKAH \\
\hline Diserahkan \\
21 November 2019 Diterima \\
28 November 2019 \\
Diterima dan Disetujui 19 \\
Desember 2019
\end{tabular}

Kata Kunci:

Farmasi,

Buang Sampah Obat, Pengabdian masyarakat, Berantas Obat Ilegal

Key Words:

Pharmacy,

Dispose of Drug Waste,

Community Service, Eradicate

Illegal Drugs

\begin{abstract}
ABSTRAK
Bulan Juli 2019, masyarakat dikejutkan dengan adanya peredaran obat ilegal dan palsu yang bersumber dari pemanfaatan obat kedaluwarsa atau rusak yang dibuang sembarangan. Hasil pengawasan Badan POM menunjukkan bahwa temuan obat ilegal dan palsu cenderung menurun, yaitu 29 perkara pada tahun 2017, 21 perkara pada tahun 2018, dan 8 perkara pada awal tahun 2019. Untuk memberantas peredaran obat ilegal dan penyalahgunaan obat, sekaligus meningkatkan derajat kesehatan masyarakat, Prodi Farmasi Universitas Muhammadiyah Palopo menerapkan kebijakan berbasis kolaboratif dan sinergis bersama lintas sektor khususnya organisasi profesi Ikatan Apoteker Indonesia (IAI) PC Kota Palopo melalui Gerakan "Ayo Buang Sampah Obat" di Kelurahan Latuppa Kecamatan Mungkajang Kota Palopo. Gerakan ini merupakan salah satu gerakan pemberdayaan masyarakat yang tidak terpisahkan dari Aksi Nasional Pemberantasan Obat Ilegal dan Penyalahgunaan Obat (Aknas POIPO) yang telah dicanangkan oleh Presiden Republik Indonesia tahun 2017 lalu. Sebagai keberlangsungan terhadap peningkatan kesehatan dan kesejahteraan melalui pencegahan peredaran obat ilegal dan penyalahgunaan obat, pada 29 September 2019 Prodi Farmasi Universitas Muhammadiyah Palopo melakukan pengabdian berjudul "Ayo Buang Sampah Obat". Melalui kegiatan pengabdian masyarakat ini, Prodi Farmasi Universitas Muhammadiyah Palopo mengedukasi masyarakat untuk waspada terhadap obat ilegal dan palsu dengan cara Buang Sampah Obat Kadaluwarsa dan Rusak dengan benar.
\end{abstract}

Abstract. In July 2019, the community was shocked by the circulation of illegal and counterfeit drugs that originated from the use of expired or damaged drugs that were discarded carelessly. The results of the supervision of the POM show that the findings of illegal and fake drugs tend to decrease, namely 29 cases in 2017,21 cases in 2018, and 8 cases in early 2019. To eradicate the circulation of illegal drugs and drug abuse as well as increasing the degree of public health, the University of Muhammadiyah Palopo Pharmacy Study Program applies collaborative and synergistic based policies together across sectors. This action was moved by especially the professional organization of the Indonesian Pharmacist Association (IAI) PC Palopo through the "Let's Remove Trash Medicine" Movement in Latuppa Village, Mungkajang District, Palopo City. This movement is one of the community empowerment movements that is inseparable from the National Action to Eradicate Illegal Drugs and Drug Abuse (Aknas POIPO), which was launched by the President of the Republic of Indonesia in 2017. As a continuation of improving health and well-being through prevention of the circulation of illegal drugs and drug abuse, on September 29, 2019, the Pharmacy Study Program at the University of Muhammadiyah Palopo conducted a service titled "Let's Remove Drug Waste." Through this community service activity, the Pharmacy Study Program at the University of Muhammadiyah Palopo educates the public to be aware of illegal and counterfeit medicines by disposing of Expired and Damaged Medicines Waste Correctly. 


\section{Pendahuluan}

Untuk menekan peredaran obat ilegal dan penyalahgunaan obat, IAI (Ikatan Apoteker Indonesia) PC Kota Palopo bekerjasama dengan Prodi Farmasi Universitas Muhammadiyah Palopo mencanangkan Kegiatan pemberdayaan masyarakat bertajuk "Ayo Buang Sampah Obat" - Gerakan Waspada Obat Ilegal dalam acara World Pharmacy Day di Kelurahan Latuppa Kota Palopo pada 29 September 2019. Aktivitas ini dilakukan serentak di beberapa kota di Indonesia.

Gerakan ini merupakan kelanjutan dari Aksi Nasional Pemberantasan Obat Ilegal dan Penyalahgunaan Obat (Aknas POIPO) yang telah dicanangkan oleh Presiden Republik Indonesia pada Tahun 2017. Melalui kegiatan ini, IAI (Ikatan Apoteker Indonesia) PC Kota Palopo bekerjasama dengan Prodi Farmasi Universitas Muhammadiyah Palopo, lintas sektor dan pelaku usaha lainnya mengedukasi masyarakat untuk waspada terhadap obat ilegal dan palsu dengan cara Buang Sampah Obat Kedaluwarsa dan Rusak dengan benar atau dapat mengembalikan obat ke Apotek-apotek bertanda khusus yang ditunjuk sebagai lokasi pengembalian obat kedaluwarsa dan rusak.

Seluruh Dosen Program Studi Farmasi Universitas Muhammadiyah Palopo, mengajak masyarakat untuk membuang sampah obat dengan benar. Obat kedaluwarsa atau rusak sudah tidak memberikan efek terapi dan berpotensi memberikan efek samping yang tidak diinginkan jika digunakan, karena itu Dosen Program Studi Farmasi Universitas Muhammadiyah Palopo mengajak masyarakat belajar cara membuang obat kedaluwarsa, obat sisa, dan obat rusak dengan benar agar tidak disalahgunakan atau dimanfaatkan oleh oknum untuk membuat obat ilegal atau palsu.

Selama bulan September sampai Oktober 2019, masyarakat dapat membuang sampah obat kedaluwarsa di beberapa apotik yang tersebar di Kota Palopo. Kegiatan ini dilaksanakan secara berkesinambungan sehingga tercipta budaya masyarakat membuang sampah obat kedaluwarsa dan rusak dengan benar, baik mandiri atau dikembalikan ke apotek terdekat untuk dimusnahkan sesuai ketentuan. Setelah Oktober 2019, masyarakat yang memiliki obat kedaluwarsa dapat melakukan pemusnahan mandiri atau dapat menyimpan obat tersebut dan mengembalikan ke Apotek sesuai jadwal pengembalian obat.

Adanya berbagai masalah tersebut maka diperlukan keikutsertaan tenaga kefarmasian dalam mewujudkan kesehatan masyarakat dengan ambil bagian dalam upaya peningkatan pelayanan kesehatan. Upaya peningkatan pelayanan kesehatan tersebut antara lain dapat dilakukan dengan memberikan informasi tentang cara buang sampah obat dengan baik dan benar. Peningkatan pelayanan kesehatan dapat diberikan pada seluruh lapisan masyarakat. 
Berdasarkan observasi tim pelaksana program pengabdian masyarakat diketahui bahwa masyarakat Kelurahan Latuppa belum pernah mendapatkan informasi tentang Buang Sampah Obat dan pengetahuan terkait penggunaan dan penanganan obat masih kurang. Tim pelaksana program memandang perlu untuk dilakukan sosialisasi pada masyarakat kelurahan Latuppa. Hasil sosialisasi diharapkan para masyarakat Kelurahan Latuppa dapat membagikan informasi tentang cara buang sampah obat serta penggunaan dan penanganan obat yang benar kepada anggota keluarganya serta masyarakat di Kelurahan lainnya. Dengan demikian, program Pengabdian Masyarakat yang berjudul "Ayo Buang Sampah Obat di Kelurahan Latuppa Kecamatan Mungkajang Kota Palopo Provinsi Sulawesi Selatan” yang diprakarsai oleh Ikatan Apoteker Indonesia (IAI) PC Kota Palopo bekerjasama dengan Prodi Farmasi Universitas Muhammadiyah Palopo dapat meningkatkan kualitas hidup masyarakat dalam upaya mencapai derajat kesehatan yang setinggi-tingginya sebagai komitmen dalam melaksanakan amanat Undang-undang Nomor 36 Tahun 2009 tentang Kesehatan dapat tercapai.

\section{Masalah}

Obat memainkan peran penting dalam mengobati berbagai kondisi dan penyakit, namun saat Anda tidak lagi membutuhkan obat-obatan tersebut, penting untuk membuangnya dengan benar untuk membantu mencegah obat tercampur-baur dengan satu sama lain.

Kimberly Cimarelli, manajer farmasi di Penn State Milton S. Hershey Medical Center, menyatakan obat-obatan yang terlalu lama disimpan mungkin sudah melewati setengah dari batas waktu pemakaian mereka, menyebabkan mereka tidak lagi bekerja dengan efektif (WebMD).

Selain itu, banyak masalah lain yang timbul apabila sampah obat tidak di kelola atau dibuang dengan baik antara lain:

a) Digunakan oleh pihak yang tidak bertanggung jawab untuk keperluan produksi obat ilegal melalui pemanfaatan baik sebagai bahan baku (re-use) dan pelabelan ulang (relabeling) dengan modus sederhana seperti perubahan/perpanjangan tanggal kedaluwarsa

b) pencemaran lingkungan

c) Dapat merusak obat lain apabila diletakkan dalam 1 tempat

d) Berbahaya jika dikonsumsi melewati masa pakainya

Dari beberapa permasalahan tersebut di atas, maka strategi yang ditetapkan untuk penyelesaian masalah tersebut adalah dengan melakukan simulasi dan edukasi kemasyarakat mengenai sampah obat. 
Berdasarkan analisis masalah di atas, maka strategi yang ditetapkan untuk penyelesaian masalah adalah dengan: (1) meningkatkan pemahaman masyarakat tentang bahaya obat kadaluarsa; (2) meningkatkan pemahaman masyarakat tentang cara pengolahan sampah obat yang baik dan benar; (3) meningkatkan kesadaran masyarakat untuk tidak membeli obat sembarangan, (5) meningkatkan pengetahuan masyarakat tentang penyimpanan obat yang baik dan benar.

\section{Metode}

Dalam melaksanakan kegiatan Pengabdian Kefarmasian “Ayo Buang Sampah Obat di Kelurahan Latuppa Kecamatan Mungkajang Kota Palopo Provinsi Sulawesi Selatan” ini, tim pelaksana membagi kegiatan dalam pembimbingan dan pendampingan menjadi beberapa tahapan, dan dapat kita lihat pada diagram alir dibawah ini :

Diagram Alir Metode Pelaksanaan Kegiatan

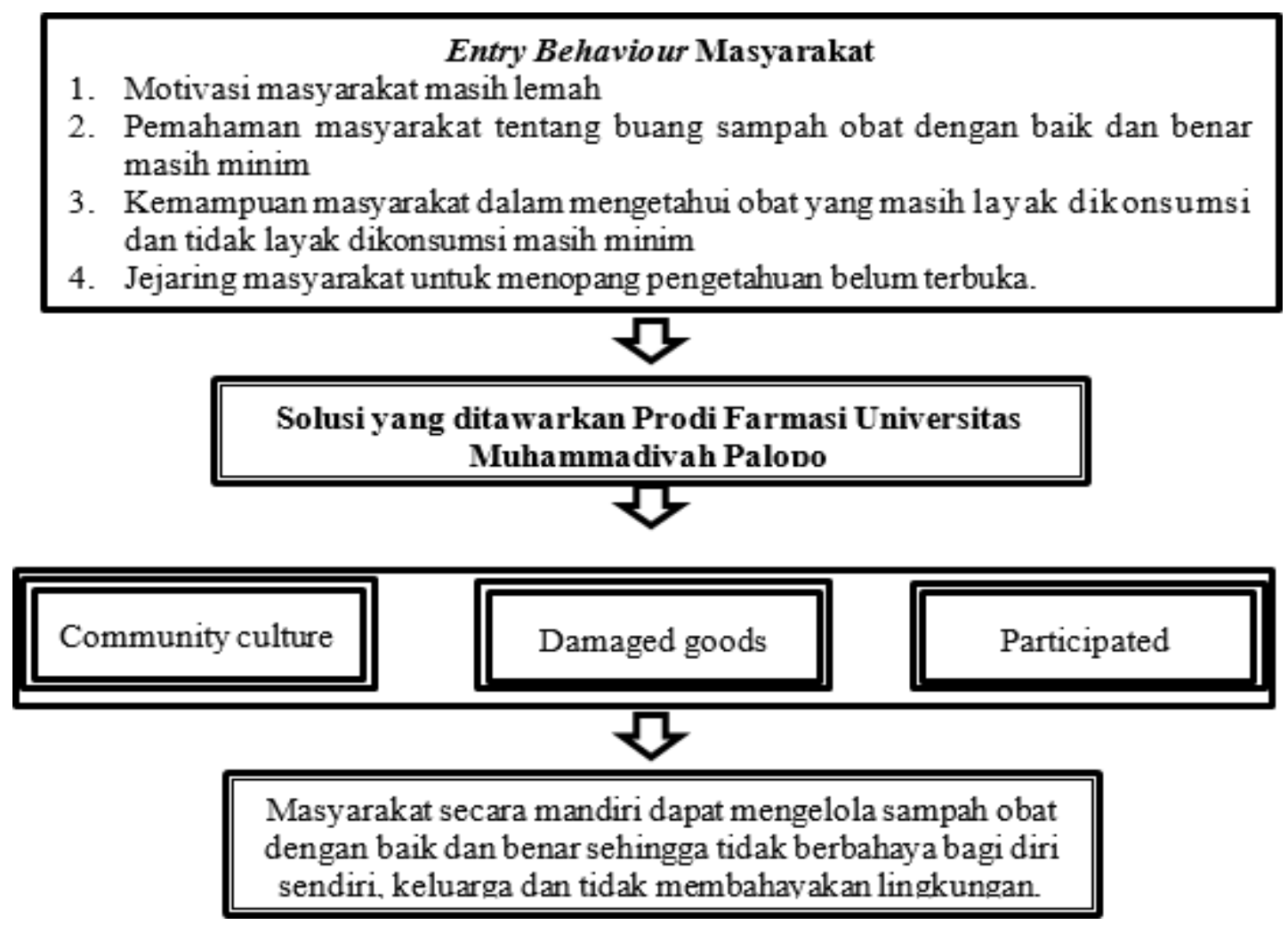

Metode yang digunakan dalam kegiatan pengabdian masyarakat ini yaitu metode pemberdayaan masyarakat partisipatif dengan model Particatory Rural Appraisal (PRA), yaitu metode yang menekankan keterlibatan masyarakat dalam semua kegiatan yang dilakukan (Lutfiyati, dkk.,2017). Tahapan dalam pelaksanaan program pengabdian masyarakat ini meliputi: 


\section{Pengenalan masalah}

Tim pelaksana melakukan survei pada mitra (Masyarakat Kelurahan Latuppa Kecamatan Mungkajang Kota Palopo) untuk melakukan pengenalan masalah yang dihadapi masyarakat terkait cara buang sampah obat. Berdasarkan hasil penelusuran diketahui bahwa masyarakat Kelurahan Latuppa tingkat pengetahuannya tentang cara buang sampah obat masih relatif rendah dan belum pernah mendapatkan sosialisasi tentang cara buang sampah obat. Tim pengusul memberikan alternatif penyelesaian masalah dengan cara memberikan sosialisasi tentang cara buang sampah obat.

2. Sosialisasi Ayo Buang Sampah Obat dengan cara penyuluhan

Kegiatan sosialisasi dilaksanakan setelah semua perijinan dan peralatan disiapkan. Kegiatan dilaksanakan di Kelurahan Latuppa. Pelaksanaan penyuluhan dilakukan oleh ketua dan angota pelaksana pengabdian dengan menjelaskan tentang cara buang obat yang benar. Penyuluhan dilakukan dengan media bantu Power Point, sehingga peserta dapat mengetahui dengan jelas bahaya buang sampah obat sembarangan dan cara buang sampah obat yang benar. Materi yang disampaikan meliputi:

- DAGUSIBU (DApatkan, GUnakan, SImpan, BUang) obat dengan benar,

- Ayo Buang Sampah Obat,

- Pelayanan Informasi Obat (PIO),

3. Diskusi dan tanya jawab

Pada sesi diskusi dan tanya jawab, peserta dipersilakan bertanya berbagai hal terkait materi yang disampaikan ataupun permasalahan tentang cara buang sampah obat serta penggunaan dan penanganan obat yang sedang dialami atau yang pernah dialami.

\section{Pembagian doorprize}

Pembagian doorprize kepada para peserta yang dapat menjawab pertanyaan terkait materi sosialisasi yang telah disampaikan tentang cara buang sampah obat serta penggunaan dan penanganan obat.

\section{Pemeriksaan Kesehatan Gratis}

Pemeriksaan kesehatan gratis dilakukan untuk membantu masyarakat mengetahui kondisi tubuhnya yang dilakukan melalui pemeriksaan tekanan darah, gula darah, kolestrol, asam urat, berat badan dan usia sel tubuh. Sehingga masyarakat mengetahui apa yang harus mereka jaga untuk tetap sehat. 


\section{Hasil dan Pembahasan}

Program pengabdian kepada masyarakat ini dimulai dengan koordinasi antara tim pengusul, Dinas Kesehatan Kota Palopo, Ketua Ikatan Apoteker Indonesia (IAI) PC Kota Palopo dan Lurah Latuppa. Pada saat koordinasi dilakukan pembahasan tentang topik permasalah dan usulan penyelesaiannya, sehingga diputuskan untuk melakukan kegiatan sosialisasi "Ayo Buang Sampah Obat”. Sosialisasi Ayo buang sampah obat dengan cara penyuluhan tentang penggunaan dan penanganan obat yang benar serta pembagian buku saku DAGUSIBU (DApatkan, GUnakan, SImpan, BUang) bagi masyarakat kelurahan latuppa telah dilaksanakan pada hari Minggu, tanggal 29 September 2019. Kegiatan dilaksanakan di Tempat Wisata Kambo Kelurahan Latuppa Kecamatan Mungkajang. Kegiatan dimulai dengan pembukaan dan sambutan oleh kepala Dinas Kesehatan Kota Palopo yang menjelaskan tujuan diadakannya kegiatan sosialisasi Ayo buang Sampah Obat. Total peserta yang hadir yaitu 67 yang merupakan masyarakat Kelurahan Latuppa. Foto peserta sosialisasi dapat dilihat pada gambar 1.

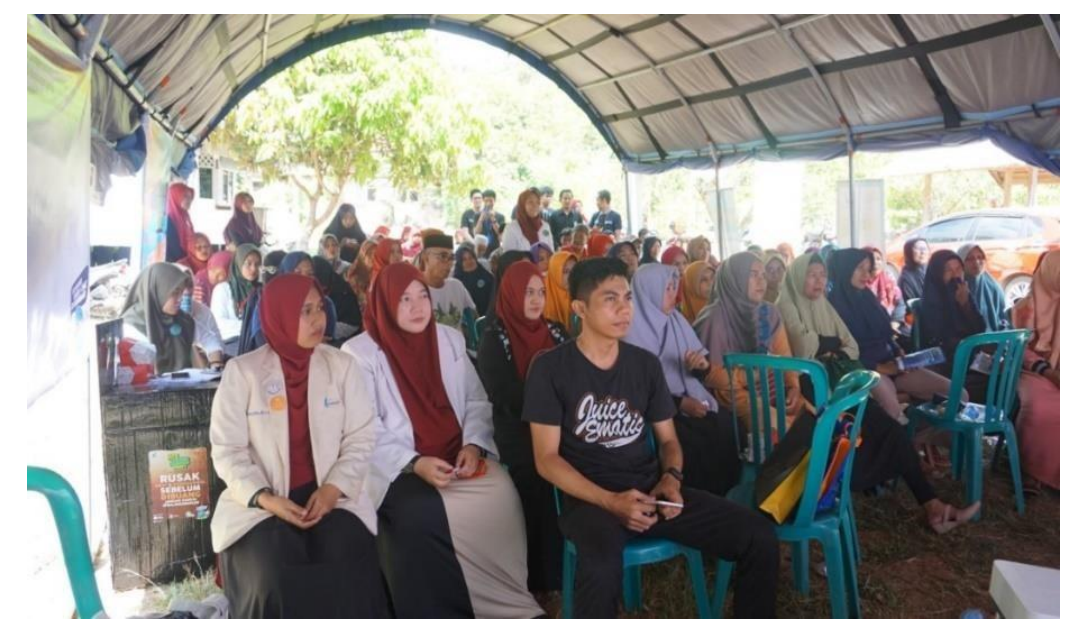

Gambar 1. Peserta Sosialisasi

Kegiatan sosialisasi diawali dengan penjelasan tentang tujuan "Ayo Buang Sampah Obat", bagaimana cara membuang sampah obat yang baik dan benar sehingga tidak membahayakan keluarga dan lingkungan sekitar, tempat membeli obat yang aman yaitu pada fasilitas kefarmasian (apotek, rumah sakit, puskesmas, klinik utama, toko obat) serta penggolongan obat. Penggolongan obat dibagi menjadi empat, yaitu obat bebas, obat bebas terbatas, obat keras, dan obat narkotika (Sumarsono, 2015). Foto kegiatan tim sosialisasi dapat dilihat pada gambar 2. 

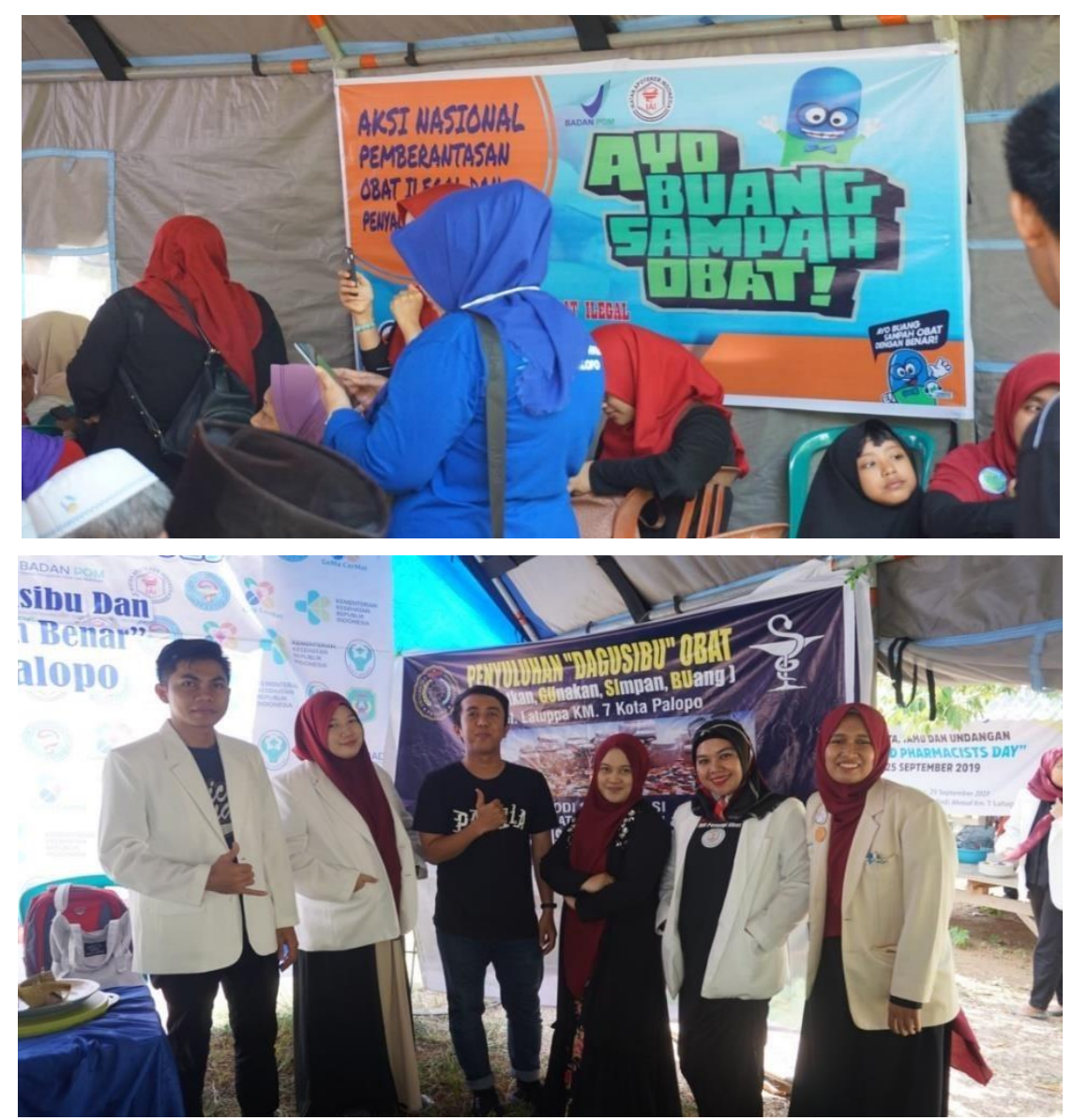

Gambar 2. Tim Pelaksana Pengabdian Masyarakat Prodi Farmasi Universitas Muhammadiyah

$$
\text { Palopo }
$$

Pada saat sosialisasi dijelaskan juga tentang hal-hal yang harus diperhatikan dalam melakukan penangan obat, yaitu melakukan pemeriksaan tanggal kadaluarsa obat dan memperhatikan cara penggunaan obat dengan benar. Tim pelaksana menjelaskan dan mempraktekkan cara pemakaian obat pada bentuk sediaan khusus. Obat dalam bentuk sediaan khusus tersebut, yaitu sediaan obat tetes mata, suppositoria, salep mata, tetes hidung, semprot hidung, semprot mulut, dan tetes telinga (Lutfiyati, et al., 2017).

Cara penggunaan obat-obat tersebut penting untuk dijelaskan karena sering terjadi kesalahan cara pemakaiannya disebabkan kurangnya informasi terkait hal tersebut. Penjelasan selanjutnya adalah tentang penyimpanan obat dengan benar sesuai dengan petunjuk penyimpanan yang tertera pada kemasan obat.

Penyimpanan obat yang tidak sesuai dapat menurunkan stabilitas obat yang pada akhirnya akan berpengaruh pada efektivitas obat tersebut dalam memberikan efek terapi. Penyimpanan obat yang tidak memerlukan kondisi khusus sebaiknya disimpan pada kotak obat yang terlindung 
dari paparan sinar matahari langsung dan tidak terjangkau oleh anak-anak. Materi terakhir yang diberikan yaitu menjelaskan tentang cara membuang obat dengan benar supaya tidak disalahgunakan oleh orang lain. Pada saat akan membuang obat terlebih dahulu harus menghilangkan semua label dari wadah obat, untuk obat berbentuk padat harus dihancurkan terlebih dahulu sebelum dibuang, sedangkan untuk obat berbentuk cair dibuang ke dalam saluran air (Lutfiyati et al. 2017).

Kegiatan sosialisai dilanjutkan dengan sesi diskusi dan tanya jawab. Para peserta yang hadir dalam sosialisasi “Ayo Buang Sampah" sangat antusias dalam mendengarkan penjelasan dan aktif bertanya terkait cara buang sampah obat, penggunaan obat dan penanganannya. Hal ini diketahui dari respon peserta dalam menanggapi kegiatan ini secara positif dan antusias. Antusiasme peserta terlihat pada saat mendengarkan dan mencatat beberapa hal sesuai penjelasan yang diberikan tentang penggunaan dan penanganan obat yang benar. Banyak peserta yang aktif bertanya tentang beberapa hal antara lain terkait pengelolaan obat, penggunaan obat yang sedang dikonsumsinya, efek samping yang ditimbulkan oleh obat yang sedang dikonsumsi.

Pertanyaan lain yang muncul yaitu tentang penggantiaan obat dengan zat aktif yang sama tetapi berbeda merk, perbedaan antara obat generik dan non generik, penggunaan obat herbal yang bersamaan dengan obat kimia. Beberapa masyarakat juga bertanya tentang kriteria kemasan obat yang baik, pemilihan obat bagi pasien yang memiliki riwayat alergi obat, makanan yang aman bagi penderita sakit kolesterol serta kepatuhan dalam meminum obat, dan masih banyak lagi pertanyaan yang lain. Foto keaktifan peserta dalam sesi diskusi dan tanya jawab dapat dilihat pada gambar 3 .

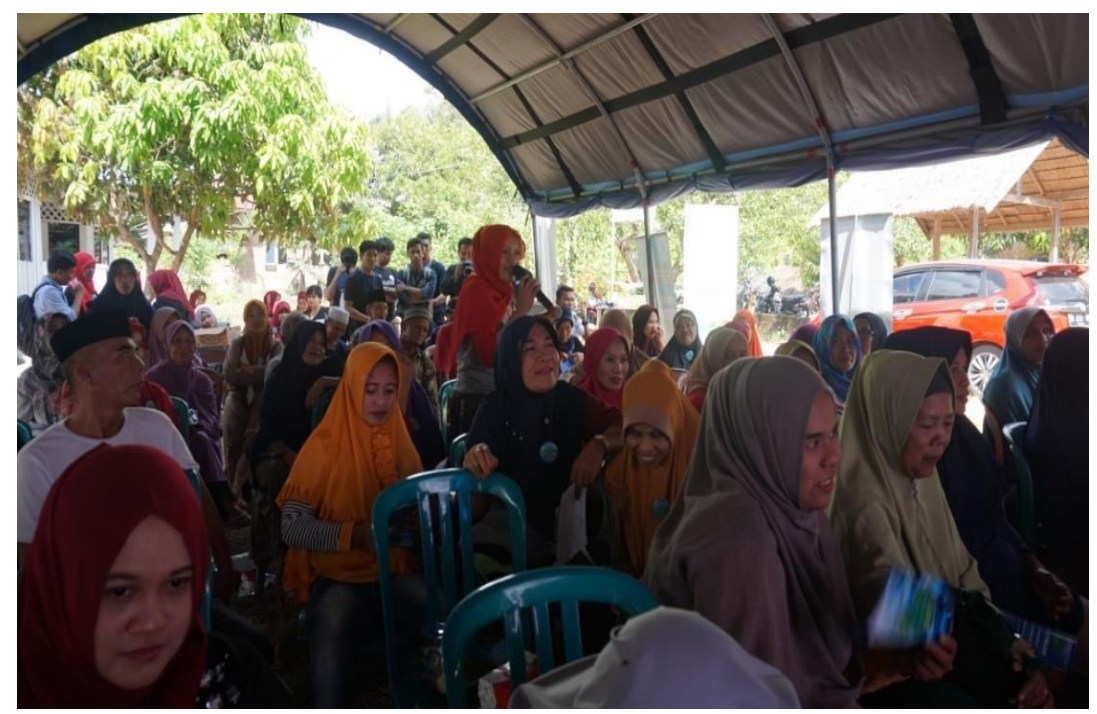

Gambar 3. Sesi diskusi dan tanya jawab 
Kegiatan sosialisasi dilanjutkan dengan acara pembagian doorprize kepada peserta sosialisasi. Doorprize diberikan kepada peserta yang dapat menjawab pertanyaan yang diajukan oleh tim pelaksana. Pertanyaan yang diajukan tentang materi yang telah disampaikan selama sosialisasi. Hal ini untuk mengetahui tingkat pemahaman peserta terkait meteri yang diberikan, selain itu doorprize yang diberikan diharapkan dapat menjadi kenang-kenangan bagi para peserta dan sebagai pengingat bahwa pernah dilakukan sosialisasi "Ayo Buang Sampah Obat" oleh Progran Studi Farmasi Universitas Muhammadiyah Kota Palopo. Foto kegiatan pembagian doorprize dapat dilihat pada gambar 4 .

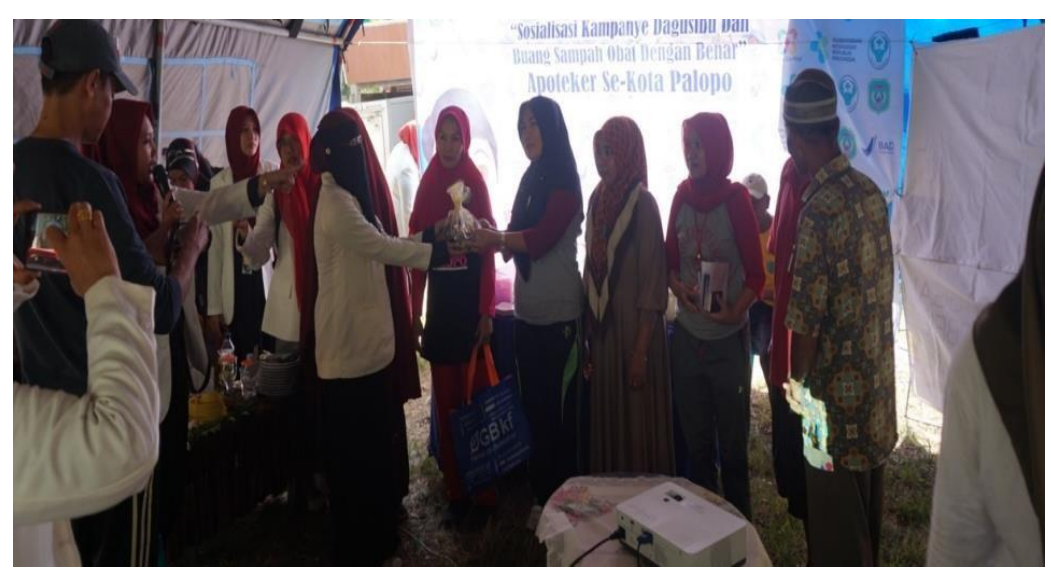

Gambar 4. Pembagian Doorprize

Kegiatan sosialisasi diakhiri dengan pemeriksaan kesehatan gratis. Kegiatan ini dilakukan untuk mengetahui kesehatan masyarakat Kel. Latuppa yaitu dengan mengecek kadar kolestrol, tekanan darah, gula darah, berat badan dan usia sel tubuh serta diberikan solusi tentang pola hidup dan obat yang sebaiknya dikonsumsi. Foto pemeriksaan kesehatan peserta sosialisasi dapat dilihat pada gambar 5 .

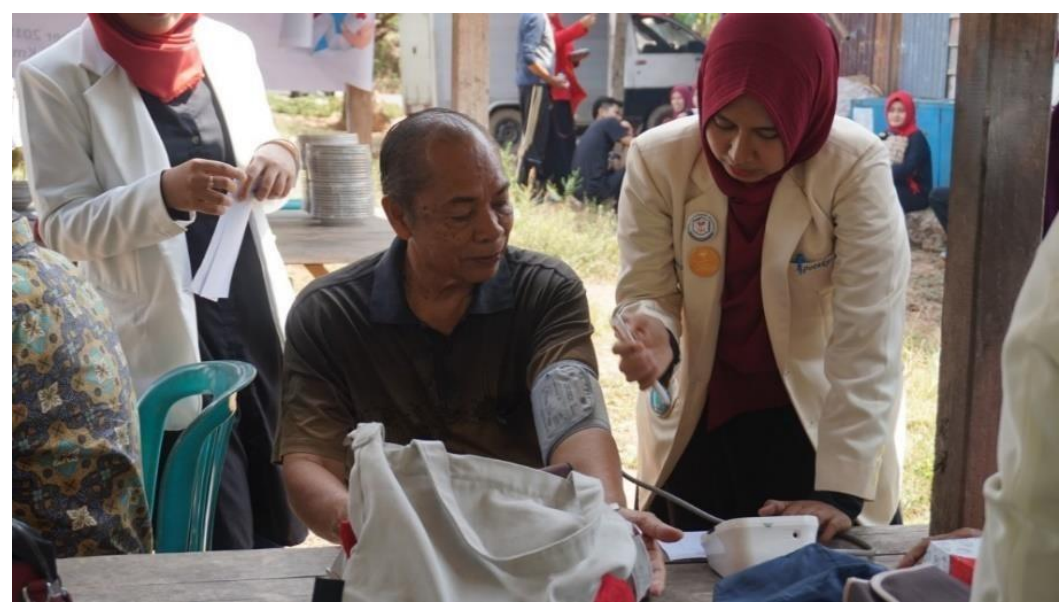

Gambar 5. Pemeriksaan kesehatan 
Pada saat awal dilakukan sosialisasi diketahui bahwa tidak semua peserta paham dan mengerti tentang cara buang sampah obat serta penggunaan dan penanganan obat dengan benar. Setelah pelaksanaan sosialisasi seluruh peserta menjadi mengerti bahwa sampah obat tidak boleh dibuang sembarangan karena bisa membahayakan keluarga dan lingkungan sekitar, pembelian obat yang benar adalah di sarana kefarmasian karena terjamin keaslian dan keamanan obatnya. Beberapa peserta sosialisasi yang pada awalnya kurang paham tentang penyimpanan obat yang benar serta tanda-tanda obat yang telah mengalami kerusakan, serta batas aman penggunaan obat setelah dibuka dari kemasan aslinya setelah pelaksanaan kegiatan menjadi lebih paham.

Penyimpanan yang tidak tepat dapat merusak obat. Mayoritas obat sebaiknya disimpan dalam suhu ruang di kotak obat yang tidak dapat dijangkau oleh anak-anak, namun ada sebagian obat yang harus disimpan dalam lemari es untuk menjaga obat tetap berkhasiat. Secara umum obat tidak boleh terpapar sinar matahari langsung, oleh karena itu, obat perlu disimpan di tempat tertutup dan kering. Obat juga harus disimpan di tempat aman, terhindar dari balita agar tidak dimakan sembarangan. Saat menerima obat hendaknya dibaca informasi terkait penggunaan obat dan cara penyimpanan yang tertera di kemasan obat. Pada saat membeli obat seharusnya menerima kemasan obat secara lengkap karena semua informasi tentang obat tersebut tercantum dalam kemasan. Sebagian besar peserta telah paham tentang cara pembuangan obat yang telah rusak atau kadaluarsa, yaitu dengan merusak obat dan bungkusnya. Hal ini telah dipahami peserta bahwa obat yang dibuang sembarangan dapat mencemari lingkungan. Obat dan kemasan yang akan dibuang jika tidak dirusak dapat memungkinkan untuk disalahgunakan oleh orang-orang yang tidak bertanggung jawab.

\section{Simpulan}

Berdasarkan hasil pelaksanaan program pengabdian kepada masyarakat dapat disimpulkan bahwa kegiatan sosialisasi "Ayo Buang Sampah Obat" dengan cara penyuluhan tentang cara membuang sampah obat yang baik dan benar serta penggunaan dan penanganan obat yang benar berjalan dengan baik dan lancar. Hal ini diketahui dari tingkat kehadiran dan keaktifan para peserta. Total peserta yaitu 67 orang. Para peserta yang hadir sangat antusias dalam mendengarkan penjelasan dan aktif bertanya terkait cara mengelola sampah obat serta penggunaan obat dan penanganannya. Sosialisasi ini meningkatkan pemahaman peserta tentang cara buang sampah obat serta pengelolaan obat dengan benar. Hasil dari kegiatan ini adalah diharapkan bagi peserta dapat menerapkan pengetahuan yang telah diperoleh dalam lingkungan 
keluarga dan masyarakat. Hal ini dapat mendukung terwujudnya program pemerintah dalam peningkatan pelayanan kesehatan bagi masyarakat.

\section{Ucapan Terima Kasih}

Kami tim pengabdian masyarakat Prodi Farmasi Fakultas Kesehatan, Pertanian dan Ilmu Kelautan Universitas Muhammadiyah Palopo mengucapkan terima kasih kepada:

1. Rektor Universitas Muhammadiyah Palopo Dr. Salju, SE., MM

2. Lembaga Penelitian dan Pengabdian Masyarakat (LPPM) Universitas Muhammadiyah Palopo.

3. Dekan Fakultas Kesehatan, Pertanian dan Ilmu Kelautan yang telah memberikan ijin untuk melaksanakan kegiatan ini.

4. Dinas Kesehatan Kota Palopo

5. Ikatan Apoteker Indonesia (IAI) PC Kota Palopo

6. Camat Mungkajang dan Lurah Latuppa

7. Seluruh Masyarakat Kelurahan Latuppa.

\section{Daftar Pustaka}

Kahan D. 2012.Entrepreneurship in Farming.Farm Management Extension Guide. Food and Agriculture Organization of The United Nations. Tersedia Pada: http://www.fao.org/docrep/018/i3231e/i3231e.pdf

Kementerian Kesehatan Republik Indonesia. (2009). Undang-Undang Republik Indonesia Nomor 36 Tahun 2009 tentang Kesehatan.Jakarta: Kemenkes RI.

Lutfiyati, H., Yuliatuti, F., Dianita, P.S. (2017). Pemberdayaan Kader PKK dalam Penerapan DAGUSIBU (Dapatkan, Gunakan, Simpan, dan Buang) Obat dengan Baik dan Benar.The 6th University Research Colloquium. Universitas Muhammadiyah Magelang. Diakses tanggal 01 Oktober 2019.

http://journal.ummgl.ac.id/index.php/urecol/article/view/1562/672.

Maziyyah, N.. (2015) Penyuluhan Penggunaan Obat yang Benar (DAGUSIBU) di Padukuhan Bakalan, Mlati, Sleman, Yogyakarta.Laporan Kegiatan Pengabdian Masyarakat. Program Studi Farmasi, Fakultas Kedokteran dan Ilmu Kesehatan Universitas Muhammadiyah Yogyakarta.diakses tanggal 01 Oktober 2019. http://repository.umy.ac.id/bitstream/handle/123456789/4169/LAPORAN\%20pen gabdian\%20DES\%202015.pdf?sequence $=1$.

Pemerintah Republik Indonesia. (2009). Peraturan Pemerintah Nomor 51 Tahun 2009 tentang Pekerjaan Kefarmasian.Jakarta: Pemerintah RI. 
Permatasari. (2017). Efektivitas Penggunaan Media Sosial Berupa Facebook dan Instagram untuk meningkatkan Pengetahuan Mahasiswa Non Kesehatan tentang Dagusibu di Universitas Muhammadiyah Purwokerto. Diakses tanggal 03 Oktober 2018.

http://repository.ump.ac.id/4163/2/Rita\%20Permatasari_BAB\%20I.pdf.

PP IAI. (2014). Pedoman Pelaksanaan Gerakan Keluarga Sadar Obat, Pengurus Pusat Ikatan Apoteker Indonesia. Diakses tanggal 07 Juni 2018.

http://iaisumbar.net/site/wpcontent/uploads/2014/09/GKSO-Pedoman-Pelaksanaan.pdf.

Sumarsono, T. (2015). Pengantar Studi Farmasi. Jakarta: Penerbit Buku Kedokteran EGC.

Syamsuni, H.A. (2016). Ilmu Resep. Jakarta: Penerbit Buku Kedokteran EGC. 